\title{
Mathematical Creative Thinking and Student Self-Confidence in the Challenge-Based Learning Approach
}

\author{
Hayatun Nufus ${ }^{1)}$, M. Duskri ${ }^{2)}$, Bahrun $^{3)}$ \\ ${ }^{1)}$ Master Student in Mathematics Education, Universitas Syiah Kuala \\ ${ }^{2)}$ Department of Tarbiyah and Teacher Training, UIN Ar-Raniry \\ ${ }^{3)}$ Department of Teacher Training and Education, Universitas Syiah Kuala \\ Corresponding author: havatunnufusgade@gmail.com
}

\begin{abstract}
The new curriculum (K13) requires a teacher to develop students' ability in order to learn and fully understand Mathematics. The important abilities needed for a student in understanding Mathematics are the creative thinking and self-confidence. The certain study is essential in order to enbance students' ability of mathematical creative thinking and self-confidence. Challenge-Based Learning is not only demanding a student to discover a solution to a problem, but also to be confident in what he bas done. The qualitative method is used in this research to describe the students' mathematical creative thinking ability and self-confidence. The subjects are six students chosen from 21 students of seventh grade at one of Junior High Schools in Aceh, Indonesia. They are the student with high, moderate, and low creative thinking ability. The research instrument is a test for creative thinking ability, a questionnaire of self-confidence and an interview guideline. The result indicates that the students with high and moderate level meet at least three indicators of creative thinking ability. They are also confident in solving the problem. In contrast, the student with low level did not reach any indicators of creative thinking ability and have poor selfconfidence.
\end{abstract}

Keywords: Challenge-based Learning, Creative thinking ability, Self-confidence.

\section{Introduction}

Mathematics is one of the knowledge that relates to the daily life, which makes students need to learn and fully understand the subject. However, the process of learning Mathematics itself is not simple due to the diverse potential and ability of students in perceiving the Mathematics concepts. Trends in International Mathematics and Science Study (TIMSS) in 2011 put Indonesia in the position of 41 of 45 entrant countries with score of 385 above Saudi Arabia, Morocco, Oman and Ghana (Kemendikbud, 2014). The low rank achieved by Indonesian students in TIMSS is the result of several factors. One of them is how Indonesian learners are poorly trained in answering the contextual questions which require reasoning ability, argumentation and creativity to solve the problems given in TIMSS.

This fact is supported by the result of Zulfia (2016) which indicates that the ability of students in mathematical creative thinking, in general, is still quite low. Despite, the ability of creative thinking ought to be part of students' achievement and one of the main priorities in learning Mathematics at the elementary to the secondary level of education. Anwar, Anees, Khizar, Naseer, and Muhammad (2012) asserted that creative thinking has a relationship with the academic achievements. The creative thinking ability in 
Mathematics learning stimulate students' skill to find out a variety of solutions or idea in solving the mathematical problems. Coelho (2015) explained that the ability to think creatively is an important concern for a teacher, so that the teacher affords to devise learning design in order to generate students' potential in using their thinking ability to solve the given problems.

Creative thinking ability in Mathematics is examined based on the fluency, flexibility, authenticity and details as the indicator to perceive creatively resulted from one's creative thinking. This idea verifies Munandar (2009) who propounded 4 (four) main components in creative thinking: fluency, flexibility, originality and elaboration. The flexibility leads to the variety of solutions or answers, which is more into problem solving methods that have more than one approach or different point of views. Originality is the approaches or ideas produced purely from one's own way of thinking, while elaboration leads to the sequence of a step to the others. In this research, the observed creative-thinking ability is the ideas and thoughts given by students in order to solve a mathematical problem and how those ideas can be implemented in solving the problem.

Besides the ability of creative thinking in Mathematics, another factor also affects the students' achievement in learning and understanding Mathematics. The factor is selfconfidence. Self-confidence is a positive attitude possessed by one who believes that he has the ability to develop a good value for himself and his surroundings. Suhardita (2011) suggested self-confidence is belief in self-ability and fully aware of the possessed capacity to further implement it effectively. In other words, students who have good selfconfidence will be more likely to actualize their potential as an inner ability that has an impact on their learning performance. It is supported by Stankov, Morony, and Lee (2013) who suggested the importance of self confidence for students to succeed in learning Mathematics. Wainia, Hamzah, Said, Miswan, Zainal, and Ahmad (2014) also reasserted that in mathematics learning, students who have high self-confidence will be more motivated and enthusiast to learn math hence the ultimate achievement of mathematics learning will be more optimal.

The indicators of self-confidence in this research are adapted from Amalia (2016), namely 1) Believe in self-ability, 2) Independent act in making decision, 3) Have a positive self-concept, and 4) Courage to express an opinion. According to the indicators mentioned, an alternative method is required in the learning process to enhance the students' ability of mathematical creative thinking and self-confidence. The learning method that triggers students to work (learning by doing) is based on daily problems or contextual problems. One of the "learning by doing" approaches that can be implemented is Challenge-based Learning.

Challenge-Based Learning $(\mathrm{CBL})$ is one of the new learning approaches that combine the problem-based learning, project-based learning and contextual learning, which emphasize in giving experiences to students in a form of knowledge based on solving the real world problem (Johnson, 2009). By applying CBL, students are given the challenges and the chances to directly interact with the phenomenon in reality to construct their understanding according to their experiences. CBL also provides the experience to unravel the real problem related to the concepts which are being studied. The purpose of CBL according to Nichols (Apple Inc., 2010) is to deliver a learning experience as relevant as possible to the problems that will be faced by students in the real world. Thereby, the ability to understand the concept will increase and more applicable in solving the problems in daily life.

One of previous researches regarding with CBL implementation have been done by Haqq (2013). He included two classes in the research, namely the implementation of the $\mathrm{CBL}$ approach and the implementation of conventional or traditional approach. The 
result of the research shows a significant increasing ability in understanding concept and mathematical reasoning in the students in Challenge-based learning approach group in compared to the students in conventional approach group. This research has some similarities to the prior research by Haqq (2013) in implementing Challenge-based learning, where the observed variable is the ability of creative thinking in Mathematics. Nevertheless, the difference with previous research is that this research does not only evaluate the ability of creative thinking but it also includes psychological study to evaluate students' self-confidence. Therefore, the result would be a review on mathematical creative thinking ability along with the students' self-confidence after the implementation of Challenge-based Learning approach. Based on the background that has been described above, the goals to be achieved in this research are to describe students' ability of mathematical creative thinking and self confidence in the Challenge-Based Learning approach.

\section{Research Methods}

The research is conducted in order to investigate the students' ability of creative thinking and their self-confidence after the implementation of CBL approach hence the qualitative research methodology is applied. The subject of this research is the seventh grade students of a junior high school in Aceh, Indonesia. It involved 21 students in one class. Then, six students were chosen based on the results of the test of creative thinking ability (Apendix A). They were consists of three category, namely high, moderate, and low ability. The instruments were questionnaire, test of creative thinking ability, and interview guidelines.

The questionnaires were used to study how students could gain the self-confidence after the implementation of CBL approach. It was distributed after a test of creative thinking. The student was interviewed to discover how the ability of creative thinking and self-confidence could be implemented by a student to solve the problems with CBL approach. The whole conversation and dialogue in the interview was recorded and transcripted. Then, it was selected based on the outcome of interview and reduced and simplified in order to gain a specific statement needed for this research.

\section{Results and Discussion}

In this study, creative thinking ability is defined as ideas or concepts given by students to solve math problems and also how the idea is applied in solving the problem. Therefore, the aspects of creative thinking ability used in this research are based on Munandar (2009), namely fluency leads to solution or various answers, flexibility leads to solve problems that have more than one ways or different perspectives, originality leads to the way or idea is purely derived from one's genuine way of thinking, and elaboration leads to the demands of one step by another. In this section, we would discuss the students' creative thinking of each groups based on the students' answer of the test following by interview.

\section{High Creative Thinking}

According to the test results, three students (EZ, RN and JU) were selected who have high creative thinking skill. The categorization was based on the fulfillment of them on the four indicators of creative thinking skills (fluency, flexibility, originality and elaboration). All of them were able to answer the question in the algebraic form correctly and clearly with specific sequential steps. So, they reach the first creative thinking indicator that is fluency. They have also achieved flexibility indicator with provide more than one accurate technique to answer a given question. The students could also deliver the unique and distinctive answer from other students based on their own 
comprehension. It was the originality indicator on the creative thinking skill. The fourth indicator of creative thinking skill, the elaboration, were indicated by their ability to understand the problem correctly, gather all information provided and relate it with the previously taught concepts so they could solve the problem in a good and correct way.

Figure 1 showed the sample students' answer of the second problem on the group of high creative thinking ability. Based on Figure 1, the student has met four indicators of critical thinking ability. He could answer the poblem with two different methods. In the first method, he uses the assumption that bigger number $=b$ and smaller number $=k$ in solving the same problem as instructed in the question. The second method, $n$ is presupposed as a smaller number and $4 n$ is a bigger number to correctly finalize the equation. Then the interview with the student (EZ) was conducted to find out more in depth how the critical thinking of students in solving problems given.

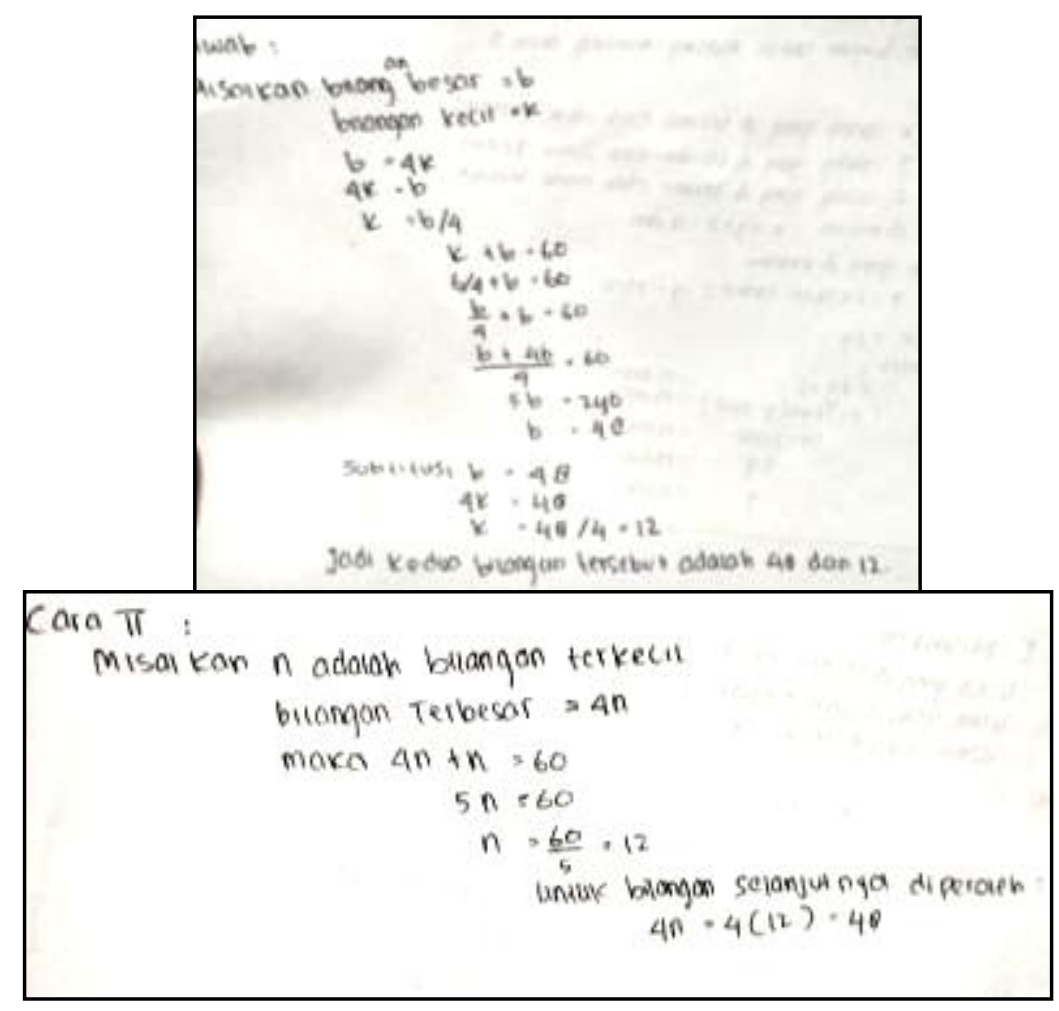

Figure 1. The sample answer of student with high creative thinking ability

Researcher : Why did you assume $n$ as the smaller number in the first method but use $k$ in the second method?

Student (EZ) : To have different ways of solving the problem. The first way was solved as instructed in the question, therefore I assumed $n$ as a smaller number. Since the question mentioned that the bigger number is 4 times the smaller number $(n)$ so it is equal to $4 \mathrm{n}$. I made the bigger number as $b$ and the smaller number as $k$ in the second method.

Researcher (R) : Why did you feel confident that the answer is correct?

Student (EZ) : Because even the question is solved in two different ways, the result or final answer is still the same. 
Based on the interview, EZ was able to explain both methods correctly and he could alter the point of view into a different perspective to solve the question. Furthermore, it can be seen that EZ fulfill the four indicators of creative thinking ability. EZ could produce several different ideas in order to make diverse techniques suitable for the problem given and elaborate it correctly. So, he has been achieved the fluency indicator. He could also alter perspective in resolving given problem by more than one technique which is an indicator of flexibility. For the originality indicator, he could give a unique answer in elaborating it through examples or in the different situation according to the algebraic form provided. The fact that EZ could give a distinctive answer to other students' by the first method made the answer is original. Finally, the elaboration indicator was indicated by offered a sequence and detailed answer and could unravel certain information by relating it to the knowledge received prior to the problem.

The ability of the students with high level of creative thinking in Mathematics have met the four indicators of creative thinking, which are fluency, flexibility, originality, and elaboration. Thus, it indicates that CBL approach can encourage students in developing their creative thinking ability, especially in learning Mathematics. Students with high level ability group relatively easily deconstruct their knowledge and adjust it to solve the given tasks. They also interact during the learning process actively, believe in their own understanding without relying on their peers or teacher, responsible to their answer, and able to communicate the work effectively.

\section{Moderate Creative Thinking}

Two students, AZ and KA, are categorized as having a creative thinking skill in the medium level. Both of them meets three indicators of creative thinking skills, namely fluency, originality, and elaboration. They could demonstrate the ability to provide an idea for solving the problem and elaborate it smoothly which is the indicator of fluency. The students were also showed the originality skill with able to comprehend and solve the question with an original answer that is different with other students'. They could also analyze the prior knowledge for unraveling given problems. Moreover, they could provide a good solution with sequential, detailed and measurable steps and also elaborate it in a clear, simple and understandable explanation. Those skills showed the elaboration indicator. However, they could not give more than one technique to solve the problem as the indicator of flexibility. They were still unsure and doubted with their solution and there was a small mistake in the propounded alternative solutions.

The sample answer of AZ is presented in Figure 2.

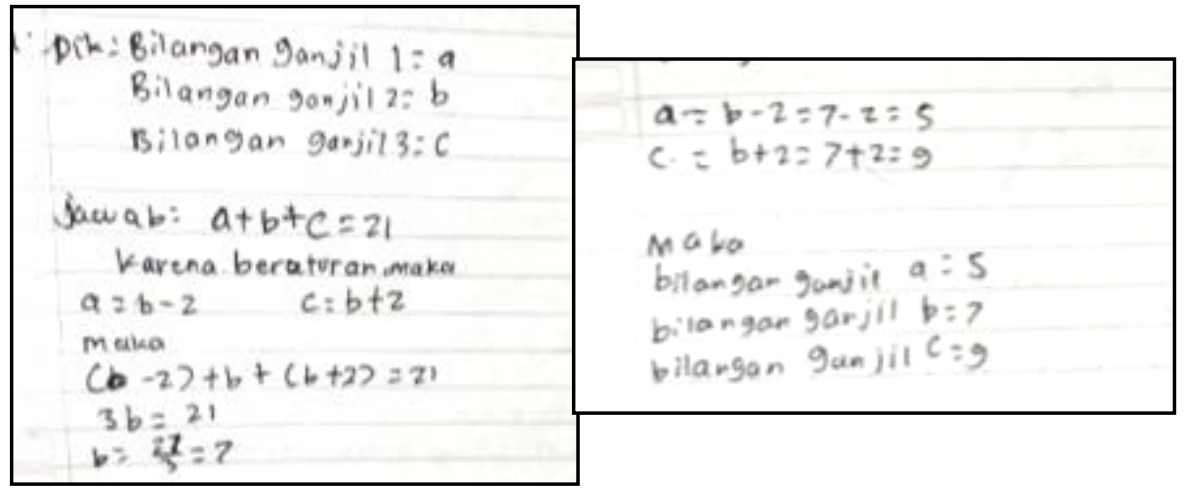

Figure 2. The sample answer of student with moderate creative thinking ability 
Based on Figure 2, it can be seen that AZ solved the problem by applying detailed steps to solve the problem. He can apply the algebraic concept previously learned appropriately. However, he only presented one solution but different from other students. The result of the interview with $\mathrm{AZ}$ is presented as follows:

Researcher : How did you define all three numbers?

Student (AZ) : I did it based on the instruction, the three numbers are odd and regularly finished hence the number must be in sequence.

Researcher : Are you sure with your answer? What is your consideration?

Student (AZ) : As I said earlier, the characteristics of the numbers are odd numbers in sequence. I then made the supposition of the three odd numbers $\mathbf{a}, \mathbf{b}$, and $\mathbf{c}$. Then $\mathbf{a}+\mathbf{b}+\mathbf{c}=21$. In the question also mentioned the number must be odd, so I made the pattern $\mathbf{a}=\mathbf{b}$ 2 , and $\mathbf{c}=\mathbf{b}+2$. Then, just replaced $\mathbf{a}$ and $\mathbf{c}$, so that $\mathbf{b}=7$, then $\mathbf{a}$ $=5$ and $\mathbf{c}=9$.

The interview showed that AZ understands the problem very well. He can describe the purpose and information provided by the problem. So, he can easily use the concept of number operations to solve the algebra problem and also the process of calculation appropriately. In addition, he is also very confident to re-explain the steps that have been done well. The results of the test and interview showed that he accurately explained in a sequential, detailed, and interrelated manner between one step and others. In addition, AZ can also explain the intended of questions and answers clearly and correctly.

\section{Low Creative Thinking}

The sample answer of $\mathrm{Z}$ who was student in the group of low creative thinking ability is presented in Figure 3.

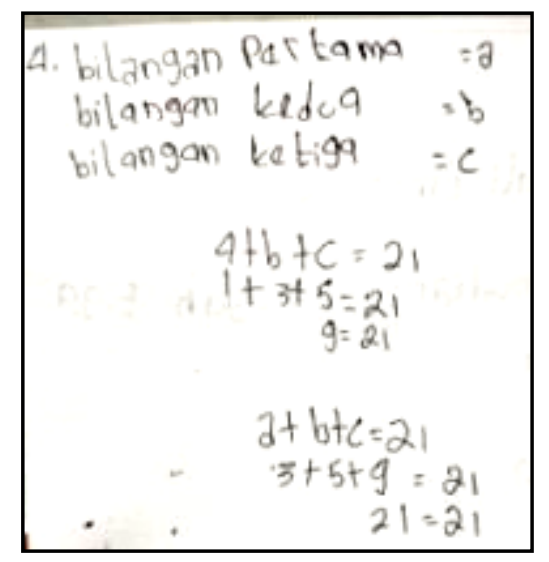

Figure 3. The sample answer of student with low creative thinking ability

$\mathrm{Z}$ answered the questions based on his understanding on the information in the questions. It can be seen in the Figure 3 that $Z$ found difficulties in understanding the question. He did not write down the information that is known and asked in the problem. He just guessed the answer randomly or by try and error. In fact, the given idea or method was very simple and incomplete or too short. $Z$ also made mistakes which resulted the wrong answer. Nevertheless, $Z$ tried to guess again the odd number which resulted an answer, 21. The interview with $Z$ regarding his solution was presented as follows. 
Researcher : Can you explain about the question number 4?

Student $(Z) \quad: \quad$ I doubt it, Miss. I don't really understand the question.

Researcher : Then how did you get this answer?

Student $(\mathrm{Z}) \quad$ : I tried to answer based on my knowledge.

Researcher : Are you sure with your answer?

Studetn $(\mathrm{Z}) \quad$ : I am not really sure, Miss.

The interview showed that the student did not understand the information contained in the problem. So that, $\mathrm{Z}$ could not find the right methods to solve the problem. $Z$ provided the answer based on his own ideas. It can be seen from the results in the Figure 3 and interview, the student with low creative thinking did not meet the four indicators of creative thinking. $Z$ was unable to provide several ways of solving the problems. He also could not explain the solution correctly. So, he did not meet the fluency indicator. $Z$ also unable to provide more than one solutions with the question related to algebraic form. The student also unable to elaborate the solution he had done. It was due to the lack of understanding of the concept of operation in an algebraic form that inhibited $Z$ to solve the problem. It means that $Z$ did not meet the flexibility indicator. Then, for the elaboration indicator, $Z$ could not analyze the information given in the test. Furthermore, $Z$ could not relate the information he had previously to solve the problem. Therefore, $\mathrm{Z}$ was considered to have low creative thinking ability and not fulfill the four criteria of creative thinking ability.

This study exhibit that the subjects have various levels of creative thinking ability, i.e. high, moderate, and low. The differences in their ability level are reflected in the results of their answer of the problems and interview. The level of the students' ability in creative thinking also mentioned by Rahmawati (2016) that the ability to think creatively is a potential possessed by every human but the degree or level is diverse from each other. Siswono (2010) also emphasized that students' ability is classified very creative if all indicators of creative thinking ability are fulfilled.

Challenge-Based Learning (CBL) approach could support the students' ability in creative thinking since the approach is not only focused on Mathematics learning, but it is also correlated to the ability in solving other tasks simultaneously. In order to answer those tasks, students are required to think creatively about delivering solutions for given questions in which those ideas are the products of creative thinking ability. Consequently, it can be assumed that giving some challenges and solving those challenges is interconnected with the students' creative thinking ability. This statement is supported by Supatmo (2011) who stated that students who apply the Challenge-based Learning approach indicate an increase in the ability to think creatively which leads to the increase in the learning outcomes, in compared with the students who implement the conventional learning approach.

Furthermore, according to the result of questionnaire for self-confidence indicators, the overall response of students' self-confidence is presented in the Table 1.

Table 1. Students' response questionnaire

\begin{tabular}{lc}
\hline Self-confidence indicators & $\begin{array}{c}\text { Percentages } \\
\text { of response }\end{array}$ \\
\hline Belief in self-ability & $70 \%$ \\
Independent act in making decision & $69 \%$ \\
Have a positive self-concept & $78 \%$ \\
Courage to express an opinion & $66 \%$ \\
\hline
\end{tabular}

Source: Data processing 
Table 1 demonstrates the result of students' self-confidence questionnaire in percentage. It shows that the response of student's self-confidence in solving the mathematical problem after the implementation of CBL approach is generally good. It means that the students have self-confident in solving the problems or challenges given to them. It is supported by the interview with the students in the group of high level creative thinking ability relatively have a very good and positive self-confidence. The interview with EZ, the student who has self confidence and high creative thinking ability is as follows.

Researcher : For the answers you have provided, did you ask others for any help?

Student (EZ) : No, Miss. I did it by myself

Researcher : Are you sure with your answer?

Student (EZ) : I am really sure

The students in this group were steady during the interview, they did not seem nervous and they were fluent in discussing their ideas. He was very confident in the answer provided and able to explain the solution he gave. Without any hesitation and shame, he could simply the answer of the questions clearly and easily to understand. It makes much clearer that EZ has a positive self-confidence hence they have no difficulties in answering the questions. Moreover, EZ also showed courage in expressing his opinion regarding with the details on the inquired solution. From the results of interview, EZ was considered as student with both high level of creative thinking ability and categorized as having good and positive self-confidence. The positive outcome of both creative thinking ability and self-confidence is definitely a good thing for the students as it will boost their performance in the learning process.

Hereafter, the self-confidence level of students in the group of moderate creative thinking ability is also good and positive. The interview with AZ, the students who has self confidence and moderate creative thinking ability is as follows.

Researcher : For the answers you have provided, did you ask others for any help?

Student (AZ) : No, Miss. I did it by myself. I just asked my friend for a part that I did not understand.

Researcher : So, do you have any difficulties in solving the question?

Student (AZ) : Only for the question that I did not understand, Miss. I just asked what the question mean. Then, I solved it by myself

Researcher : Are you sure with your answer?

Student (AZ) : Yes, I am sure

During the interview, AZ was very comfortable which made it easy for the interviewer to interview them. However, he was relatively shy during the interview. He seemed quiet and sometimes hesitated in answering the question given by the interviewer. For some questions he considered easy, AZ's answers was elaborated smoothly without any doubt and clumsiness. So, it can be concluded that AZ have a good and positive self-confidence. He only needs to be encouraged in expressing his opinion.

In contrast, the students with low level of creative thinking ability can be classified into the negative and poor level of their self-confidence. The interview with one of the subjects with low creative thinking ability is presented as follows. 
Researcher : For the answers you have provided, did you ask others for any help?

Student $(Z) \quad$ : Yes, I asked my friend because I did not understand, Miss. I was afraid I would provide wrong answer if I did it by myself

Researcher : Which question did you not understand thus you had to ask your friend?

Student $(\mathrm{Z}) \quad$ : (Kept quiet and looked at the questions)

During the interview, the student seemed unfocused, too quiet and hard to express his own thought. He even could not elaborate his own solution for the given tasks properly. However, even though $\mathrm{Z}$ was quiet, unfocused during the interview, did not listen to the interviewer, and ignored the instruction, he was willingly to be honest with his answer. He was being honest about the fact that he asked friend during the test and even had some difficulties to complete the tasks. Thus, it affected the result as he obtained a very low score. The main reason is because he was discouraged to ask the teachers for help, did not fully understand the instruction given by teachers, and preferred to ask his friend for help. The result of interview shows that $\mathrm{Z}$ who is categorized into low creative thinking ability also has a negative self-confidence. He still needs extra attention from the teacher in order to fix the lack of understanding on Mathematics.

This finding is supported by Tajudin and Jailani (2013) who emphasized that CBL approach is considered to have positive contribution to enhance effective aspects in a student. It is shown in the process of presenting a solution and implementing a strategy which gives a chance to the students to deconstruct their self-ability, potential or talent in themselves.

\section{Conclusion}

Based on the finding of the research, it can be concluded that the CBL approach encourages students to think creatively and have confidence in solving the problems. Nevertheless, some students still have low creative thinking ability and poor on their selfconfidence after implementing the CBL approach. The students with high creative thinking ability meet all indicators of creative thinking, i.e. fluency, flexibility, originality, and elaboration. The students could produce different ideas in order to make diverse techniques suitable for the problem. They could alter perspective in resolving given problem by more than one technique. They also give a unique answer in elaborating it through examples or in the different situation according to the algebraic form provided. They could also unravel certain information by relating it to the knowledge received prior to the problem. Meanwhile, the student with moderate level meet three indicators of creative thinking, namely fluency, originality, and elaboration. The students could not give more than one technique in solving the problem. They were still unsure and doubted with their solution. Therefore, they did not meet the flexibility indicator of creative thinking. The results of the interview indicate that the student with high and moderate creative thinking ability have good and positive self-confidence. The students were very confident in the answer the problem and able to explain the solution clearly and easily to understand. They have no difficulties in answering the questions. They also showed courage in expressing their opinion regarding with the details on the solution although needs supporting for student with moderate level.

In contrast, the students with low level did not meet any indicators of creative thinking ability. The students did not understand the information contained in the problem. So, they could not find the appropriate methods to solve the problem. They could not analyze the information given in the test. Thus, they could not relate the 
information to solve the problem. The results of interview showed that the students with low level of creative thinking seemed unfocused, too quiet and hard to express his own thought. They could not elaborate their own solution for the given tasks properly. They need extra attention from the teacher in order to fix the lack of understanding on Mathematics.

\section{Bibliography}

Amalia, Y. (2014). Penerapan Model Eliciting Activities untuk Meningkatkan Kemampuan Berpikir Kreatif Matematis dan Self Confidence Siswa SMA. Jurnal Didaktik Matematika. (), 38-38

Anwar, N. M., Aness, M., Khizar, A., Naseer, M., and Muhammad, G. (2012). Relationship of Creative Thinking with Academic Achievements of secondary School Students. International Interdisciplinary Journal of Education, 1(3), 44-47.

Apple, Inc. (2010). Challenge Based Learning: A Classroom Guide. Apple, Inc. . 22-25.

Bungin. (2010). Analisis Data Penelitian Kualitatif Pemahaman Filosofis Dan Metodologi Ke Arah Penguasaan Model Aplikasi. Jakarta: PT Raja Grafindo Persada.

Coelho, A., \& Cabrita, I. (2015). A Creative Approach to Isometries Integrating Geogebra and Italic with 'Paper and Pencil' Environments. Journal of the European Teacher Education Network, 10(1), 71-85.

Haqq, A. A. (2013). Penerapan Challenge based Learning Dalam Upaya Meningkatkan kemampuan pemahaman konsep dan penalaran matematis siswa SMA. Tesis. Bandung: Universitas Pendidikan Indonesia. 5-6.

Johnson, Laurence F., Smith, Rachel S., Smythe, J. Troy., and Varon, Rachel K. (2009). Challenge-Based Learning: An Approach for Our Time. Austin, Texas: The New Media Consortium. 3-10.

Kemendikbud. (2014). Konsep dan Implementasi Kurikulum. Retrieved from: http:///kemdikbud.go.id/kemdikbud/dokumen/Paparan/Paparan\%20Wam endik.pdf.

Lauster, P. (1990). Personality test Alih Bahasa D. H. Gulo. Jakarta: Bumi Aksara.

Munandar, U. (2009). Pengembangan Kreativitas Anak Berbakat. Jakarta: Rineka Cipta.

Rahmawati. (2016). Tingkeat Berpikir Kreatif Siswa dalam Pemecahan dan Pengajuan Masalah Matematika melalui Tipe Soal Open Ended di SMP. Thesis. Banda Aceh: Universitas Syiah Kuala.

Siswono, E. Y. T. (2010). Levelling Student's Creative Thinking in Solving And Posing Mathematical Problem. IndoMs. J. M. E. 1(1), 17-40.

Stankov, L., Morony, S., and Lee, Y.P. (2013). Confidence: the Best non-Cognitive Predictor of Academic Achievement. International Journal Educational Research. 34 (1), 9-28.

Sugiyono. (2012). Metode Penelitian Pendidikan: Pendekatan Kuantitatif, Kualitatif, dan R\&D. Bandung: Alfabeta. 92.

Suhardita, K. (2011). Efektifitas Penggunaan Teknik Permainan dalam Bimbingan Kelompok untuk Meningkatkan Percaya Diri Siswa. Jurnal UPI, Edisi Khusus. 10( ), 127-138.

Supatmo, J.P. (2011). Penerapan Challenge Based Learning untuk meningkatkan penguasaan konsep listrik dinamis dan Keterampilan berpikir kreatif siswa SMA.Tesis. Bandung: Universitas Pendidikan Indonesia.

Tajuddin, S. M., and Jailani, A. (2013). Challenge-Based Learning in Students for Vocational Skills. International Journal of Independent Research and Studies (IJIRS). 2 (2), 89-94. 
Wainia, I., Hamzah, K., Said, R.M., Miswan, N.H., Zainal, N.A., and Ahmad, A. (2014). Self Confidence in Mathematics. International Journal for Innovation Education and Research. 2 (11).

Wijaya, Ariyadi. (2012). Matematika itu Asyik untuk SMP. Yogyakarta: MOBIUS.

Zulfia. (2016). Peningkatan kemampuan berpikir kreatif matematis dan motivasi siswa sekolah menengah pertama melalui penerapan pendekatan problem solving. Thesis. Banda Aceh: Universitas Syiah Kuala. 


\section{APENDIX A}

\section{The Test of Creative Thinking Ability}

1. Pak yogi gave Rp15.000,00 to his three children. The second child was given Rp 2,500.00 more than the third. The first child gets three times from the second. How much does each child earn?

2. The sum of two numbers is 60 , and the larger number is four times smaller. What number is that?

3. Age of father four times his child's age. five years later, father's age three times his child's age. Determine each age of father and child?

4. The sum of 3 consecutive positive odds is 21 . Find the three numbers

5. A BANK, where Pak Dani save, was having anniversary. Pak Dani got the prize money Rp 960 million. The prize will be shared to his wife, five sons, and four daughters. Mr. Dani also divides with the stipulation that every boy earns a one and a half times the share earned by each daughter and each daughter earns twice the amount received by their mother. How much money does a girl receive? (Ariyadi Wijaya (2012). Matematika itu Asyik untuk SMP) 